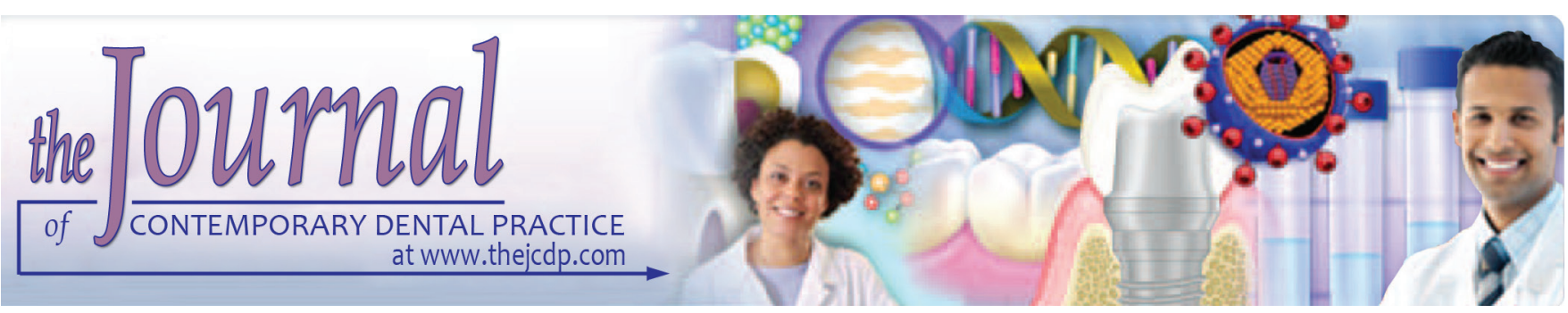

\title{
Accuracy of Working Length Determination using NovApex and Root-ZX Apex Locators: An in vitro Study
}

\author{
${ }^{1}$ Vahid Zand, ${ }^{2}$ Saeed Rahimi, ${ }^{3}$ Paria Davoudi, ${ }^{4}$ Abubakr Afshang
}

\begin{abstract}
Introduction: This ex vivo study evaluated the accuracy of the Root-ZX electronic apex locator (EAL) (J. Morita, Tokyo, Japan) and the NovApex (Forum Technologies, Rishon Lezion, Israel) in determining the working length $(\mathrm{WL})$ during endodontic treatment.

Materials and methods: Forty extracted single-rooted human teeth were selected for this study. The actual WL was measured with visual technique by a size \#15 k-file under magnification. Then, the canal lengths were measured electronically with both Root-ZX and NovApex apex locators within \pm 0.5 and $\pm 1 \mathrm{~mm}$. Mean percentage of data was analyzed between groups using paired t-test, with a statistically significant level of $p<0.05$.
\end{abstract}

Results: The accuracy of NovApex apex locator was $85 \%$ within $\pm 0.5 \mathrm{~mm}$ and $92.5 \%$ within $\pm 1 \mathrm{~mm}$. The accuracy of Root-ZX apex locator was $70 \%$ within $\pm 0.5 \mathrm{~mm}$ and $97.5 \%$ within $\pm 1 \mathrm{~mm}$. There was no significant difference between the accuracy of the two EALs.

Conclusion: Both the NovApex and Root-ZX EALs are useful for measuring the WL with high accuracy.

Clinical significance: Given the importance of accurate WL determination in the success of endodontic treatments, the accuracy of different apex locators should be evaluated.

Keywords: Electronic apex locator, NovApex, Root-ZX.

How to cite this article: Zand V, Rahimi S, Davoudi $P$, Afshang A. Accuracy of Working Length Determination using NovApex and Root-ZX Apex Locators: An in vitro Study. J Contemp Dent Pract 2017;18(5):383-385.

Source of support: Nil

Conflict of interest: None

${ }^{1-3}$ Department of Endodontics, Faculty of Dentistry, Tabriz University of Medical Sciences, East Azerbaijan, Islamic Republic of Iran

${ }^{4}$ Private Office, East Azerbaijan, Islamic Republic of Iran

Corresponding Author: Paria Davoudi, Department of Endodontics, Faculty of Dentistry, Tabriz University of Medical Sciences, East Azerbaijan, Islamic Republic of Iran, Phone: +989144045938, e-mail: davoudiparia1991@gmail.com

\section{INTRODUCTION}

A proper determination of working length $(\mathrm{WL})$ is one of the main factors of successful root canal therapy. ${ }^{1}$ The $\mathrm{WL}$ is defined as the distance from a coronal reference point to the apical point at which canal preparation and obturation should end. ${ }^{2}$

As the apical constriction is the narrowest region of the canal, many studies have suggested this region as the apical reference and because of the smallest blood supply diameter in this region, healing would be desirable and the wound to the periapical tissues is supposed to be minimum. ${ }^{3}$

Conventional measurement methods for determining WL are periapical radiographs and electronic apex locators (EALs). To decrease radiographic exposure and the rate of overestimation of root canal length, EALs are broadly used in endodontics to determine WL during root canal treatment. ${ }^{4,5}$ Nowadays, the most broadly used EAL is Root-ZX (J. Morita, Tokyo, Japan), which concurrently measures the impedance values at two frequencies $(0.4$ and $8.0 \mathrm{kHz}$ ) and then calculates their quotient. ${ }^{6}$

The other EAL that has attracted attention is NovApex (Forum Technologies, Rishon Lezion, Israel) that uses voltage difference and operates based on the principle that in addition to the difference of impedance measurement between two electrodes, it shows a great difference at an apical constriction region. ${ }^{7}$

The purpose of this ex vivo study was to evaluate and compare the accuracy of Root-ZX and NovApex in determining WL.

\section{MATERIALS AND METHODS}

Forty extracted, single-rooted, human maxillary incisors with mature apices and straight roots, which have been randomly selected, were used in this study. Canals with open apices, root fractures, obstructed foramina, previous root perforations, and accessory canals were excluded from the sample. After the soaking of teeth (samples) in 
$2.5 \%$ sodium hypochlorite for 3 hours, they were stored in sterile $0.9 \%$ saline until used.

Access cavity was performed with fissure and round diamond burs, and a flat horizontal plane was prepared with a diamond bur to provide a fixed coronal reference point for all measurements.

The distance from coronal reference plane to apical foramen was considered as the actual root canal length. A size \#15 k-file (Maillefer, Dentsply) with a silicone rubber stop was inserted, until its tip was just visible at the level of apical foramen. This procedure was performed under a magnifying glass at a magnification of $\times 15$ and an explorer. After adjusting the silicone rubber to the coronal reference and removing the fileclip from the root canal, the actual root canal length was measured with an endodontic ruler (mm). According to the estimated distance between apical foramen and apical constriction based on Kuttler and Dummer's studies, we calculated the WL by subtracting $0.5 \mathrm{~mm}$ from the measured length. 8,9

Electronic measurements were achieved using the Root-ZX and NovApex. For electronic WL determination, a screw top plastic container was filled with an electrolyte, which was a buffer solution containing $\mathrm{Na}_{2} \mathrm{HPO}_{4}$ (4.5 gm), $\mathrm{NaCl}(7 \mathrm{gm})$, and $\mathrm{KH}_{2} \mathrm{PO}_{4}(6.67 \mathrm{gm})$ in $1 \mathrm{~L}$ of distilled water. The tooth and a conductor metal bar with a loop at the top were inserted through the screw top perforated with two holes.

The tooth position was adjusted until the root was inserted into the buffer solution and the file clip of the EAL was attached to the loop of the bar. Then a size \#15 k-file with attached file clip of the EAL was inserted into the canal until it reached the apex and the apex locator started to provide rapid audible signaling. The silicon rubber was then adjusted on the specimen and the penetration depth was recorded.

The electronic WL measurements were recorded per canal and both apex locators, Root-ZX and NovApex, for further statistical analysis.

\section{Data Analysis}

Data were analyzed by Statistical Package for the Social Sciences software (version 17/0: SPSS Inc., Chicago, IL, USA). The significance level was set at $p=0.05$. The accuracy of NovApex and Root-ZX apex locators was calculated within \pm 0.5 and $\pm 1 \mathrm{~mm}$. Paired $t$-test was used to compare the accuracy of the two EALs.

\section{RESULTS}

There was an extreme correlation between visual $\mathrm{WL}$ determination and Root-ZX and NovApex measurements. The accuracy of NovApex apex locator was $85 \%$ within $\pm 0.5 \mathrm{~mm}$ and $92.5 \%$ within $\pm 1 \mathrm{~mm}$. The accuracy of
Root-ZX apex locator was $70 \%$ within $\pm 0.5 \mathrm{~mm}$ and $97.5 \%$ within $\pm 1 \mathrm{~mm}$. There was no significant difference between the accuracy of two EALss in WL determination $(\alpha<0.05)$.

\section{DISCUSSION}

A successful endodontic treatment depends on many fundamental factors, in which one of the key factors is accurate WL determination. To eliminate the problems of radiographic method, the use of EALs for determining WL has become increasingly popular.

The main purpose of this ex vivo study was to evaluate the accuracy of one EAL most widely used in clinical practice, the Root-ZX, and another brand, the NovApex.

Since the introduction of EALs, numerous in vitro and in vivo studies have evaluated the accuracy of these devices in determining WL. In a study by Shabahang et $\mathrm{al}^{10}$ the reported value for Root-ZX was $96.2 \%$. In another study, Pagavino et al ${ }^{11}$ showed that the Root-ZX was accurate $82.75 \%$ within $\pm 0.5 \mathrm{~mm}$ and $100 \%$ within $\pm 1 \mathrm{~mm}$ in determining WL from apical foramen. D' Assunção et al ${ }^{12}$ in an ex vivo study showed that the accuracy of NovApex in determining the apical foramen was $82.1 \%$ within $\pm 0.5 \mathrm{~mm}$. The apical end point used in that study was the apical foramen. The difference between these studies is in appointing the reference point from which measurement accuracy is determined. Some authors measured from the minor diameter, while others measured from the major foramen or apical foramen. The apical limit in our study was apical constriction $(0.5 \mathrm{~mm}$ shorter than apical foramen), and the results of our study showed that the accuracy of the Root-ZX was $70 \%$ within $\pm 0.5 \mathrm{~mm}$ and $97.5 \%$ within $\pm 1 \mathrm{~mm}$, whereas it was $85 \%$ within $\pm 0.5 \mathrm{~mm}$ and $92.5 \%$ within $\pm 1 \mathrm{~mm}$ for NovApex.

In another in vitro study, which had been done in retreatment cases, the electronic measurements obtained with NovApex showed an accuracy of $85 \%$ (within $\pm 0.5 \mathrm{~mm}$ of the apical foramen). ${ }^{13}$ In an in vivo study conducted by Shahi et al ${ }^{14}$, it was concluded that the accuracy of NovApex apex locator was more than traditional radiographic technique (74.7 vs 68\%). Furthermore, one study evaluated the ability of NovApex in detecting the position of the horizontal root fracture in extracted teeth and showed the accuracy of $70 \%$ within $\pm 0.5 \mathrm{~mm}$ of the fracture line. ${ }^{15}$

In general, we can say that similar to previous studies, ${ }^{12,13}$ our study showed no significant difference between Root-ZX and NovApex.

\section{CONCLUSION}

From this study, it can be concluded that both NovApex and Root-ZX apex locators are useful for measuring the WL with high accuracy. 


\section{ACKNOWLEDGMENT}

The author would like to thank the Research Vicechancellor of Tabriz University of Medical Sciences for financial support of this research project.

\section{REFERENCES}

1. Ng YL, Mann V, Rahbaran S, Lewsey J, Gulabivala K. Outcome of primary root canal treatment: systematic review of the literature - part 2. Influence of clinical factors. Int Endod J 2008 Jan;41(1):6-31.

2. American Association of Endodontists. Glossary of endodontic terms. 9th ed. Chicago: American Association of Endodontists; 2015.

3. Ricucci D. Apical limit of root canal instrumentation and obturation, part 1. Literature review. Int Endod J 1998 Nov;31(6):384-393.

4. ElAyouti A, Weiger R, Löst C. The ability of root ZX apex locator to reduce the frequency of overestimated radiographic working length. J Endod 2002 Feb;28(2):116-119.

5. Ravanshad S, Adl A, Anvar J. Effect of working length measurement by electronic apex locator or radiography on the adequacy of final working length: a randomized clinical trial. J Endod 2010 Nov;36(11):1753-1756.

6. Kobayashi C, Suda H. New electronic canal measuring device based on the ratio method. J Endod 1994 Mar;20(3):111-114.

7. D'Assunção FL, de Albuquerque DS, de Queiroz Ferreira LC. The ability of two apex locators to locate the apical foramen: an in vitro study. J Endod 2006 Jun;32(6):560-562.
8. Dummer PM, McGinn JH, Rees DG. The position and topography of the apical canal constriction and apical foramen. Int Endod J 1984 Oct;17(4):192-198.

9. Wu MK, Wesselink PR, Walton RE. Apical terminus location of root canal treatment procedures. Oral Surg Oral Med Oral Pathol Oral Radiol Endod 2000 Jan;89(1):99-103.

10. Shabahang S, Goon WW, Gluskin AH. An in vivo evaluation of Root ZX electronic apex locator. J Endod 1996 Nov;22(11): 616-618.

11. Pagavino G, Pace R, Baccetti T. ASEM study of in vivo accuracy of the Root ZX electronic apex locator. J Endod 1998 Jun;24(6): 438-441.

12. D'Assunção FL, Albuquerque DS, Salazar-Silva JR, Dos Santos VC, Sousa JC. Ex vivo evaluation of the accuracy and coefficient of repeatability of three electronic apex locators using a simple mounting model: a preliminary report. Int Endod J 2010 Apr;43(4):269-274.

13. Goldberg F, Marroquín BB, Frajlich S, Dreyer C. In vitro evaluation of the ability of three apex locators to determine the working length during retreatment. J Endod 2005 Sep;31(9):676-678.

14. Shahi S, Rahimi S, Milani AS, Asghari Jafarabadi M, Djoorabbaf Naghsh GR. Comparison between the accuracy of novapex apex locator and radiographs in determining radiographic apex. Iran Endod J 2011 Spring;6(2):65-68.

15. Goldberg F, FrajlichS, KuttlerS, Manzur E, Briseño-Marroquín B. The evaluation of four electronic apex locators in teeth with simulated horizontal oblique root fractures. J Endod 2008 Dec;34(12):1497-1499. 